\title{
Multilingual Competences and Labour Market Access: The Point of View of Swiss Personal Advisers in the Regional Employment Centres
}

\author{
Seraphina Zurbriggen ${ }^{1}$, Isaac Pante ${ }^{1}$, Pascal Singy ${ }^{1,2, *}$ \\ ${ }^{1}$ Faculty of Arts: Section Des Sciences Du Langage et de L'Information, Lausanne University, Lausanne, Switzerland \\ ${ }^{2}$ Faculty of Biology and Medicine, Department of Psychiatry, Lausanne University, Lausanne, Switzerland
}

Email address:

info@seraphinazurbriggen.ch (S. Zurbriggen), isaac.pante@unil.ch (I. Pante), pascal.singy@unil.ch (P. Singy)

*Corresponding author

\section{To cite this article:}

Seraphina Zurbriggen, Isaac Pante, Pascal Singy. Multilingual Competences and Labour Market Access: The Point of View of Swiss Personal Advisers in the Regional Employment Centres. International Journal of Language and Linguistics.

Vol. 5, No. 6, 2017, pp. 161-171. doi: 10.11648/j.ij11.20170506.11

Received: August 13, 2017; Accepted: September 4, 2017; Published: September 28, 2017

\begin{abstract}
Since the creation of regional employment centres in Switzerland, personal advisers and consultants have been playing an important role in the assessment of the unemployed and the jobseekers' language skills and their promotion. In this study, 646 of these personal advisers from the three main speaking areas of Switzerland (French, German and Italian) were interviewed via an online questionnaire on how they practically assess the language skills of the jobseekers they deal with; on the reasons they do or not recommand and provide language courses; and on how these courses should be financed. There were also more general questions about the link between language skills and the labour market. Statistically significant differences were observed, for instance regarding the quality of the language-competence evaluation tools; the evaluated importance of language skills for labour market integration; and the relevance of language courses for jobseekers. A correlation was observed between these significant differences and two factors: the linguistic area and the unemployment rate in a given area. Some problematic issues of political interest linked to language skills and job recovery were also highlighted and discussed in this paper.
\end{abstract}

Keywords: Multilingualism, Switzerland, Labour Market, Advisers of Employment Centres, Representations

\section{Introduction}

This research project has been carried out in collaboration with the Research Centre on Multilingualism in Switzerland, which achieves applied research on current social issues concerning multilingualism on behalf of the Confederation. ${ }^{1}$ While researchers at this centre have conducted an ethnographic study of unemployed people in their search for employment, this project aims to address the socially relevant question of the role played by language skills when it comes to accessing the labour market. This is addressed by exploring personal advisers' views of the measures which should be prescribed to unemployed and jobseekers or, in

1 The legal basis is art. 12 of the Languages Ordinance, which is state law based on the Law of Languages. other words, their representations of this issue.

\subsection{The Role of the Personal Advisers in the Regional Employment Centres (REC)}

More than twenty years ago (in 1995) the law on Swiss unemployment insurance introduced in 1982 was reassessed for the second time. The revision resulted in the foundation of the cantonal operated Regional Employment Centres (REC) and in the development of labour market measures $(\mathrm{LMM}){ }^{2}$ Almost ten years later Magnin $[1,2]$ stated that this revision caused the professional personnel advisers (PA) of the REC to occupy a challenging double role in this environment: they advise jobseekers (JOS) and help them find jobs while simultaneously supervising their application

2 The legal basis is art. $85 \mathrm{~b}$ and $\mathrm{c}$ as well as art. 113 sect. $2 \mathrm{c}$ in the AVIG. 
efforts. Ever since, the PA play an important role as "gatekeepers" $\left[3^{3}\right]$ for the labour market. Thus, on the one hand they have to reconcile the tasks of the established practice with the laws while on the other hand they must show a certain level of humanity.

These legal bases are defined in the Unemployment Insurance Act (UIA) as well as in the Unemployment Insurance Regulation (UIR) regarding the obligations of the PA and the JOS. ${ }^{4}$ The JOS have the obligation to come to the scheduled appointment and to provide information about their job seeking activities. They have to document their active job search in particular and participate in LMM. This active application effort in the form of a quid pro quo of the JOS to the State has been strongly criticised by Magnin. She considers this activation policy "authoritarian, pedagogising and not adequate in a democratic constitutional state" [2: 359] and assumes that it restricts rather than encourages the JOS' awareness of their responsibilities. In addition to the tasks of advice and mediation, the PA also increasingly need to keep these efforts under constant review. They can impose sanctions against the JOS if they don't meet their obligations. ${ }^{5}$ Moreover, the PA have the statutory mandate to decide whether any LMM need to be prescribed to the JOS, and if so which one, in order to promote quick and permanent labour market integration. ${ }^{6}$ They can oblige the JOS to participate in specific LMM. Regarding this regulation there are educational and employment measures or specific measures such as induction or training subsidies at the PAs' disposal. ${ }^{7}$ When prescribing these individual measures, the PA not only have to aim for a quick and durable labour market integration, but simultaneously keep an eye on the budget for LMM within their cantonal requirements. In order to meet the different challenges and requirements, the PA need to develop personal strategies and preferences for certain LMM that are oriented towards both the nationally recognised guidelines of the State Secretariat for Economic Affairs (SECO) and the guidelines of the cantonal Employment Offices. The most frequent financial measures concern education and mainly include assessment courses and job application training (approx. 46'000

3 The authors describe the problem of " gatekeeping ", the role of academic student advisers and the question if students with a social background and style of communication similar to that of the advisers have advantages.

4 In art. 17 of the AVIG the duties of the insured person and control provisions are defined. In art. 22 of the AVIV counselling interview and control consultation is regulated and in art. 23 of the AVIV the information obligation of the JOS is regulated.

5 In art. 30 of the AVIG the conditions that could lead to eligibility of benefits are explained.

6 In art. 59 sect. 2 of the AVIG the use of LMM is explained as follows: „Labour market measures are meant to promote integration of insured persons that are difficult to place due to reasons related to the labour market. Such measures should notably: a. improve the employability of insured persons so they can be reintegrated immediately and permanently; b. foster professional qualifications according to labour market needs; c. decrease the risk of long-term unemployment; or d. provide the opportunity to gain work experience."

7 The educational measures are described in art. 60 sect. 1 of the AVIG, the employment measures are described in art. 64a sect. 1 of the AVIG and the special measures are described in art. 65 to 71 of the AVIG and art. 90 to 95 e of the AVIG. participants in 2010, [4] as well as language courses (approx. 20 '000 participants). Language courses are among the PAs' preferred LMM.

\subsection{Language as an Additional Benefit in the Professional World of Today}

Although the notion that language skills are decisive in the process of labour market entry is widespread, specific studies in Switzerland on that matter are scarce $[5,6,7,8]$. In order to overcome this deficit and for the following reasons the focus of this research is placed on language skills:

1. Switzerland's professional world of today is shaped by globalisation and migration: over one third of the Swiss population are first and second generation immigrants with different language skills. ${ }^{8}$ Moreover, the different linguistic regions are characteristic of the Swiss working world and language skills in the national languages often represent a linguistic capital [10], and therefore imply an additional benefit. The national languages and the so-called world languages appear to be particularly wage-relevant. There is a hierarchy in the national languages, not only with respect to the economic value of the different language skills $[11,12,5]$, but also with reference to their use in the workplace $[13,8]$. The first question of our research addresses the additional benefit of the different language skills and how the PA assess this linguistic capital in the different languages.

2. At a structural level differences in the unemployment rate along the Swiss linguistic frontiers have been observed for a long time $[14,15,16]$ : In the German-speaking cantons the average unemployment rate today is still lower (2.4\%) than in the French-speaking cantons $(5.3 \%)$ or Ticino $(4.6 \%){ }^{9}$ The difference between the German-speaking and the French/Italian-speaking areas can be explained with the different probability of finding a job in the particular language region due to the economic situation [15]. Compared to the labour force, a study on employment history of jobseekers also shows [14] that people without Swiss nationality from large French- and Italian-speaking regions, with low education levels and from certain professions show an increased risk for one or more periods of unemployment. Therefore the question which arises is whether the PA also have different representations regarding the connection between language skills and labour market integration in the three linguistic regions, the German-speaking, Frenchspeaking and Italian-speaking parts of Switzerland, given the different unemployment rates. Social representations are understood in the terms of Laplantine, who defines them as individuals' knowledge of a piece of their existence in a given society or social group [18: 278]. The focus here is on the representations of the PA depending on the language region, namely concerning the additional benefit of language

8 See permanent resident population (from the age of 15 up) by migration status in 2013: [9].

9 See unemployment rate by cantons in February 2015; while in the evaluation the mean values have been calculated without the bilingual cantons Berne, Valais and Fribourg: [17]. 
skills discussed above, but also concerning the importance of language skills regarding labour market integration alongside other individual factors.

3. Arguably, the function of the PA refers not only to the allocation of governmental services, but also to the assessment of the JOS' language skills and their market value, when it comes to the disposal of language courses as LMM. During registration (and processing of the files), various personal data is entered by the employees of the REC and regularly updated if required in accordance with the regulation concerning the information system for job placement and the labour market statistics (AVAM). They also register the language skills, whereby the competences are recorded either as "native language" or as oral and written partial competences in second languages. The latter are assessed in four levels: very good knowledge, good knowledge, basic knowledge, no knowledge. This registration is based on information from the JOS (selfassessment or resume), which the PA validate or correct after discussions.

Before the PA prescribe language courses, they have to assess whether these could facilitate the JOS' reintegration into the labour market. The prescription of LMM has the institutional purpose of a) quick and b) permanent labour market (re)integration of the insured person (as stated in the AVIG, cf. footnote 8). ${ }^{10}$ The question arises whether the PA pursue different objectives in assigning JOS to language courses.

Based on these three main considerations, the following research questions about the representations of the PA concerning the influence of language skills in labour market integration will be at the core of this paper:

Which language skills represent an additional benefit in which linguistic regions according to the PA?

How do PA consider the importance of language skills and other individual factors regarding labour market integration? Are there differences depending on the linguistic region?

What are the benefits of the prescription of language courses as LMM according to the PA? Are there differences depending on the linguistic region?

\section{Survey Methodology}

\subsection{Creation of the Questionnaire}

The research being lead through a survey, its first step was the creation of a questionnaire. The questionnaire comprised 31 questions (24 closed and 7 open questions) and was first created in French and transformed into an online version through the programme LimeSurvey ${ }^{11}$. This version was next translated into German and Italian and then translated back in order to receive identical language versions. All three language versions were tested by several people with the respective mother tongue. ${ }^{12}$

10 See State Secretariat for Economic Affairs (SECO), AVIG, LMM, [19]

11 This programme has already been used by Kaltenborn and Kaps for their survey [20] with the REC and JOS and has been approved of by the authors (personal message from Kaltenborn).

12 Moreover, tests with different browsers regarding the recording of the survey

\subsection{The Survey Procedure}

The directors of the cantonal employment offices of the 26 (demi) cantons have been asked for permission to implement the survey in their canton via e-mail. Of the 26 cantons queried, the following 18 have agreed to participate: Appenzell Innerrhoden, Appenzell Ausserrhoden, Berne, Basel-Country, Basel-City, Geneva, Glarus, Grisons, Nidwald, Obwald, Schaffhausen, Solothurn, Schwyz, Ticino, Uri, Vaud, Valais and Zug. In most cantons, the link was distributed directly to the PA via the cantonal offices on the 3rd of June, 2014. ${ }^{13}$ A second invitation to participation was sent on the 30th of June 2014 and the survey ended on the 15 th of July 2015. A total of 814 people participated in the survey and $79.4 \%$ finished the questionnaire $(n=646)$. It was decided against a third request due to the high response rate and to the upcoming summer holidays.

\subsection{Content of the Questionnaire}

In addition to the socio-demographic data, the 31 questions cover three areas: a) the handling, the representations and the improvement suggestions of the PA regarding the current assessment of language skills methods, b) the representations of the PA regarding the additional benefit and the importance of language skills for labour market integration and c) the evaluation of the existing tools regarding the improvement of language skills. In this paper, only three questions of the above presented questionnaire will be described and discussed.

Additional benefit of the different language skills in the language regions

The question concerning the additional benefit of the assessment of language skills was: "In your experience, in which professions can the mastery of one of the following national languages be an additional benefit when it comes to finding work in the linguistic region of your REC?" To answer this question, the following languages were presented: Switzerland's three official languages (standard German, French and Italian), ${ }^{14}$ dialectal varieties of Standard German known as Swiss German, ${ }^{15}$ the most common languages spoken by migrants namely Portuguese, Spanish, Albanian, Serbo-Croatian, and English which is considered as the international language. In order to determine the importance of the different language skills, one to four

\footnotetext{
data have been carried out. There were no problems with LimeSurvey regarding the browsers or the data recording.

13 Exceptions were the cantons Schwyz, Solothurn and Ticino, where the distribution was conducted via REC employers, and the canton Grisons, where only six employers have been surveyed.

14 Rhaeto-Romanic has not been taken into account as it has the status of a semiofficial language at federal level (cf. art. 70, sect. 1 in the Swiss Federal Constitution and art. 5, sect. 1 in the Federal Law of national languages and the understanding between language communities).

15 In the largest language area, the German-speaking part, the numerous mutually intelligible dialectal varieties (= Swiss German varieties) coexist with Swiss standard German in a diglossic situation. They are used regularly, mainly orally, in a wide range of public and private settings. The standard variety, on the other hand, is confined to a limited number of situations, such as teaching and written use.
} 
professions were chosen in each three economic sectors in relation to unemployment [21]. Since most of the registered unemployed come from the tertiary sector, ${ }^{16}$ four of the eight professions have been taken from this sector. In addition, as a means of comparison with other professions from the tertiary sector, healthcare professions were also represented since a lot of people are employed in this profession and have to rely on their linguistic skills. The following professions were selected as prototypes of professions of the particular sectors: Sector 1: agricultural assistant; Sector 2: road builder, mechanic; and Sector 3: salesperson, hotel receptionist, service employee, bank employee and nursing aid.

\section{The importance of language skills}

In order to capture the representations of the PA regarding the importance of language skills for labour market integration, the following question was asked: "Could you evaluate according to their importance the factors that help JOS find work?" Alongside the JOS' language skills, five other individual characteristics were evaluated on a scale from "not important" to "very important." The five following individual factors have emerged as central elements in labour market integration during the exploratory interviews as well as in the literature: JOS' motivation, JOS' social contacts [22] along with JOS' personal "savoir être") as well as professional capabilities ("savoir faire" [23]). The latter professional expertise has been recorded in the questionnaire under the two aspects work experience and job references.

The benefits of collective language courses

It can be argued that the main benefits of collective language courses, alongside the acquisition of language skills, to be a) quick and b) permanent labour market integration. The acquisition of language skills can be considered as achieving a good level in the language(s) of the canton (for low-skilled JOS with insufficient knowledge) ${ }^{17}$ or achieving a minimum level in a different language. Moreover, during the exploratory interviews, REC employees have stated that compulsory language courses also aim to assess the JOS' motivation and to thus perform a controlling function. Several PA would furthermore like to promote the integration of foreign JOS with the help of linguistic LMM. The PA could reply to the following statements on a 4-grade scale from "not agreeing" to "completely agreeing": generally speaking, in their opinion, the collective language courses of the LMM contribute to integrate the JOS into the labour market, to reach a minimum level of the language of the canton, to reach a minimum level of a different language, to assess the JOS' motivation, to

16 At the time of the survey preparation in May 2014 that was precisely $69 \%$.

17 In the publication „Deutsch für den Arbeitsmarkt, Rahmenkonzept für Projektverantwortliche und Lehrpersonen" commissioned by SECO, this aspect is emphasised: "Low-skilled jobseekers often find it difficult to gain a foothold in the labour market. Due to their origin, many have little knowledge of the national language. For this group, sufficient language skills are an often underestimated key competency: Not only because it lays the foundations for job searching, but also because it enables adaptation to changing requirements at the workplace and the attendance of further training." [23: 3]. The work has also been published in French: "Du français pour travailler. Un concept cadre pour responsables de projets et de cours" [24]. promote integration of the foreign JOS and to reduce relapse into unemployment.

\subsection{Response Rate and Description of Samples}

Table 1. Sample description.

\begin{tabular}{|c|c|c|c|}
\hline$N=646$ & Modality & $\begin{array}{l}\text { Absolute } \\
\text { frequency }\end{array}$ & $\begin{array}{l}\text { Relative } \\
\text { frequency }\end{array}$ \\
\hline \multirow[t]{5}{*}{ Age } & $20-29$ & 16 & $2.5 \%$ \\
\hline & $30-39$ & 141 & $21.8 \%$ \\
\hline & $40-49$ & 212 & $32.8 \%$ \\
\hline & $50-59$ & 209 & $32.3 \%$ \\
\hline & over 60 & 54 & $8.3 \%$ \\
\hline \multirow[t]{2}{*}{ Sex } & female & 325 & $50.3 \%$ \\
\hline & male & 301 & $46.6 \%$ \\
\hline \multirow[t]{3}{*}{ Linguistic region } & German-speaking & 279 & $43.2 \%$ \\
\hline & French-speaking & 299 & $46.3 \%$ \\
\hline & Italian-speaking & 68 & $10.5 \%$ \\
\hline \multirow[t]{4}{*}{ Level of education } & Apprenticeship & 129 & $19.9 \%$ \\
\hline & $\begin{array}{l}\text { Bachelor or Higher } \\
\text { School Certificate }\end{array}$ & 60 & $9.3 \%$ \\
\hline & $\begin{array}{l}\text { Degree (University or } \\
\text { Technical College) }\end{array}$ & 288 & $44.6 \%$ \\
\hline & other & 146 & $22.6 \%$ \\
\hline \multirow[t]{4}{*}{$\begin{array}{l}\text { Years of activity at the } \\
\text { REC }\end{array}$} & $0-4$ & 182 & $28.1 \%$ \\
\hline & $5-9$ & 145 & $22.4 \%$ \\
\hline & $10-14$ & 119 & $18.4 \%$ \\
\hline & 15 and more & 177 & $27.4 \%$ \\
\hline \multirow[t]{2}{*}{ Leadership function } & yes & 101 & $15.6 \%$ \\
\hline & no & 510 & $78.8 \%$ \\
\hline \multirow[t]{3}{*}{$\begin{array}{l}\text { Declared } \\
\text { multilingualism }\end{array}$} & 1 & 122 & $18.9 \%$ \\
\hline & 2 & 222 & $34.4 \%$ \\
\hline & 3 or more & 282 & $43.7 \%$ \\
\hline \multirow[t]{4}{*}{ Unemployment rate } & $0-1.9 \%$ & 41 & $6.3 \%$ \\
\hline & $2-2.9 \%$ & 214 & $33.1 \%$ \\
\hline & $3-3.9 \%$ & 151 & $23.3 \%$ \\
\hline & over $4 \%$ & 230 & $35.5 \%$ \\
\hline
\end{tabular}

Remarks:

- The total of the relative frequency does not result in $100 \%$ with most variables, since figures are missing and the percentage values always refer to 646 people.

- Linguistic region: Apart from three exceptions, all PA have replied in the official regional language in which "their" REC is located. - Unemployment rate: The five categories of unemployment rate have been taken from SECO while the two categories $<1 \%$ and $1-1.9 \%$ were merged. The unemployment rate of this evaluation refers to the month of the survey, June 2014, the data has been published by SECO on https://www.amstat.ch/v2/index.jsp (5.2.2015).

646 PA fully completed the questionnaire out of a total of 1'204 respondents. ${ }^{18}$ This results in an extremely high response rate of $54 \%$. The questioned REC advisers (sociodemographic characteristics see table 1) are both male and female and on average older than 40. They have completed higher professional training, are multilingual and on average have already been working at the REC for many years. When compared to the distribution of French-speaking people in Switzerland $(22.6 \%),{ }^{19}$ this sample shows a significant

18 In the written statement from SECO, the number of PA in the whole of Switzerland was 2'309 on the $31^{\text {st }}$ of December 2013. When calculated with the participating cantons this was 1'204 PA.

$1922.6 \%$ of the sample from the confederate structure survey from 2012 indicated French as one of their main languages [25]. 
overrepresentation of French-speaking advisers among the questioned PA (46.3\%). It is noticeable that the unemployment rate in the cantons from the sample pretty accurately corresponds to the Swiss average rate of $3.2 \%$ in 2014 [26]. The median of $3.3 \%$ shows that half of the participating PA worked in a canton in which the unemployment rate was $\geq 3.3 \%$ at the time of the survey and the other half of the PA worked in a canton in which the rate was $<3.3 \%$.

\section{Results}

Regarding the first question on the additional benefits of the individual languages, the percentage values will be presented in a descriptive form for each linguistic region (German-, French- and Italian-speaking). Regarding the second and third question on the importance of language skills in connection to labour market integration and LMM, descriptive values will also be presented along with statistical tests (one-way ANOVA) calculated with the variable of the linguistic region.

\subsection{The Additional Value of Language Skills}

It is not surprising that the PA considered the local language as the most important language in each linguistic region, practically regardless of the job (Tab. 2). However this was not the case for salespersons and for bank or hotel reception employees. According to the surveyed PA in German-speaking regions, French has an additional benefit at hotel receptions $(83.5 \%)$ and in banks $(64.5 \%)$ in particular; as well as Italian for receptionists $(67.0 \%)$. PA in the French-speaking region similarly assume that German represents an additional benefit for receptionists $(86.0 \%)$ as well as bank employees (79.6\%); and Italian for receptionists $(41.8 \%)$. In the Italian-speaking region French is useful for jobs at the reception (79.4\%) and in banks $(51.5 \%)$, while the German language is considered useful for an even larger number of professions: bank employees $(97.1 \%)$, receptionists $(97.1 \%)$, service employees (86.8\%), salespersons (80.9\%) and nursing aids (58.8\%) benefit from these language skills according to the PA. It should also be added that according to the PA Swiss German is not only an additional benefit in German-speaking Switzerland but also in the Romance-language areas and in particular in Italian-speaking Switzerland.

Apart from Switzerland's national languages, the questioned PA consider English the most valued foreign language. English serves as lingua franca in all of the previously mentioned service occupations, $95.3 \%$ of Frenchspeaking PA for instance consider this language useful for receptionists. The most useful language spoken by migrants is Portuguese. However, the respondents see its additional benefit primary in road construction jobs (up to 69.2\%) and in agricultural holding (up to 49.8\%). According to the PA, the languages spoken by migrants Spanish, Albanian and Serbo-Croatian generate most benefits in road construction jobs (up to $41.5 \%$ ), while Spanish is also considered useful at the reception in all linguistic regions. The maximum values mentioned in parentheses can all be found in the Frenchspeaking PAs' questionnaires, which indicates that a greater benefit is attributed to the languages spoken by migrants there than in the German-speaking region.

Table 2. Percentage values of the PA that see an "additional benefit" in the languages per professional activity in the three linguistic regions.

\begin{tabular}{|c|c|c|c|c|c|c|c|c|c|c|}
\hline & Linguistic Region & $\mathbf{G}$ & $\mathbf{F}$ & I & CH-G. & Portug. & Span. & Alban. & Serbo. & Engl. \\
\hline \multirow[t]{3}{*}{ Agricultural assistant } & $G(n=279)$ & 62.7 & 5.0 & 5.4 & 54.5 & 28.3 & 13.6 & 6.5 & 5.0 & 2.9 \\
\hline & $F(n=299)$ & 2.0 & 65.6 & 3.3 & 5.4 & 49.8 & 24.1 & 16.7 & 14.7 & 1.3 \\
\hline & $\mathrm{I}(\mathrm{n}=68)$ & 7.4 & 2.9 & 70.6 & 8.8 & 23.5 & 8.8 & 5.9 & 5.9 & 4.4 \\
\hline \multirow{2}{*}{ Bank employee } & $F(n=299)$ & 79.6 & 87.6 & 8.4 & 40.5 & 4.7 & 16.4 & 0.3 & 0.7 & 91.3 \\
\hline & $\mathrm{I}(\mathrm{n}=68)$ & 97.1 & 51.5 & 77.9 & 55.9 & 1.5 & 16.2 & 0.0 & 1.5 & 91.2 \\
\hline \multirow[t]{2}{*}{ Mechanic } & $G(n=279)$ & 77.4 & 12.9 & 4.3 & 47.0 & 4.7 & 5.4 & 3.6 & 3.2 & 24.4 \\
\hline & $I(n=68)$ & 38.2 & 8.8 & 77.9 & 11.8 & 2.9 & 0.0 & 2.9 & 1.5 & 17.6 \\
\hline \multirow[t]{3}{*}{ Salesperson } & $G(n=279)$ & 80.6 & 54.1 & 19.4 & 73.1 & 6.8 & 8.2 & 7.2 & 5.4 & 63.1 \\
\hline & $\mathrm{F}(\mathrm{n}=299)$ & 41.1 & 88.3 & 6.0 & 17.1 & 8.4 & 7.0 & 2.7 & 2.7 & 73.2 \\
\hline & $I(n=68)$ & 80.9 & 32.4 & 72.1 & 51.5 & 0.0 & 2.9 & 0.0 & 0.0 & 64.7 \\
\hline \multirow[t]{3}{*}{ Receptionist (hotel) } & $\mathrm{G}(\mathrm{n}=279)$ & 88.9 & 83.5 & 67.0 & 53.4 & 12.9 & 33.0 & 5.7 & 6.1 & 90.0 \\
\hline & $F(n=299)$ & 86.0 & 93.0 & 41.8 & 39.5 & 11.4 & 30.8 & 2.3 & 2.3 & 95.3 \\
\hline & $\mathrm{I}(\mathrm{n}=68)$ & 97.1 & 79.4 & 85.3 & 77.9 & 8.8 & 29.4 & 0.0 & 4.4 & 92.6 \\
\hline \multirow[t]{2}{*}{ Service employee } & $\mathrm{G}(\mathrm{n}=279)$ & 81.7 & 49.1 & 30.1 & 68.8 & 7.9 & 15.1 & 6.8 & 7.2 & 67.0 \\
\hline & $\mathrm{I}(\mathrm{n}=68)$ & 86.8 & 36.8 & 82.4 & 61.8 & 8.8 & 17.6 & 1.5 & 2.9 & 72.1 \\
\hline \multirow[t]{3}{*}{ Road builder } & $\mathrm{G}(\mathrm{n}=279)$ & 68.5 & 4.3 & 31.9 & 37.6 & 35.8 & 28.0 & 17.2 & 14.3 & 4.7 \\
\hline & $F(n=299)$ & 1.7 & 68.2 & 14.0 & 2.0 & 69.2 & 41.5 & 31.4 & 24.4 & 1.3 \\
\hline & $\mathrm{I}(\mathrm{n}=68)$ & 7.4 & 1.5 & 79.4 & 2.9 & 14.7 & 11.8 & 7.4 & 7.4 & 4.4 \\
\hline \multirow[t]{3}{*}{ Nursing aid } & $G(n=279)$ & 79.2 & 12.0 & 10.0 & 73.1 & 12.2 & 11.8 & 7.9 & 9.7 & 20.4 \\
\hline & $\mathrm{F}(\mathrm{n}=299)$ & 8.7 & 87.0 & 4.0 & 9.0 & 17.1 & 15.1 & 5.4 & 5.4 & 26.1 \\
\hline & $\mathrm{I}(\mathrm{n}=68)$ & 58.8 & 25.0 & 80.9 & 26.5 & 4.4 & 8.8 & 1.5 & 2.9 & 32.4 \\
\hline
\end{tabular}

Remarks:

- Linguistic region: $\mathrm{G}=$ German-speaking region, $\mathrm{F}=$ French-speaking region, $\mathrm{I}=$ Italian-speaking region, $\mathrm{n}=$ number of questioned people

- language skills: $\mathrm{G}=$ German, F= French, I=Italian, CH-G= Swiss German, Portug.= Portuguese, Span.= Spanish, Alban. = Albanian, Serbo. = SerboCroatian, Engl. = English 


\subsection{The Importance of Language Skills}

The PAs' answers confirm the multifactorial nature of labour market integration. A vast majority (93\%) sees motivation as a very important factor for labour market integration (Figure 1), although other aspects like personal skills ("savoir-être"), work experience, social contacts, job references and language skills are identified as crucial for a successful job search by the majority of PA. This is the case if you combine the response categories "important" and "very important" (between $87 \%$ and $97 \%$ of respondents). Language skills are not an exception, as $91 \%$ of respondents assess them likewise.
If you scale these answers, the order of the individual factors in Figure 1 then corresponds to the descending importance of the mean values (mean values and standard deviations see table 3). The standard deviations (SD) show that the PA agree most on the importance of motivation $(\mathrm{SD}=0.3)$ and less when it comes to social contacts $(\mathrm{SD}=0.7)$. These inter-individual congruences or discrepancies are also confirmed by the anovas in table 3 , where no significant differences regarding the evaluation of motivation and work experience between the PA of different languages appear. Differences are evident regarding the remaining individual factors such as social contacts or language skills.

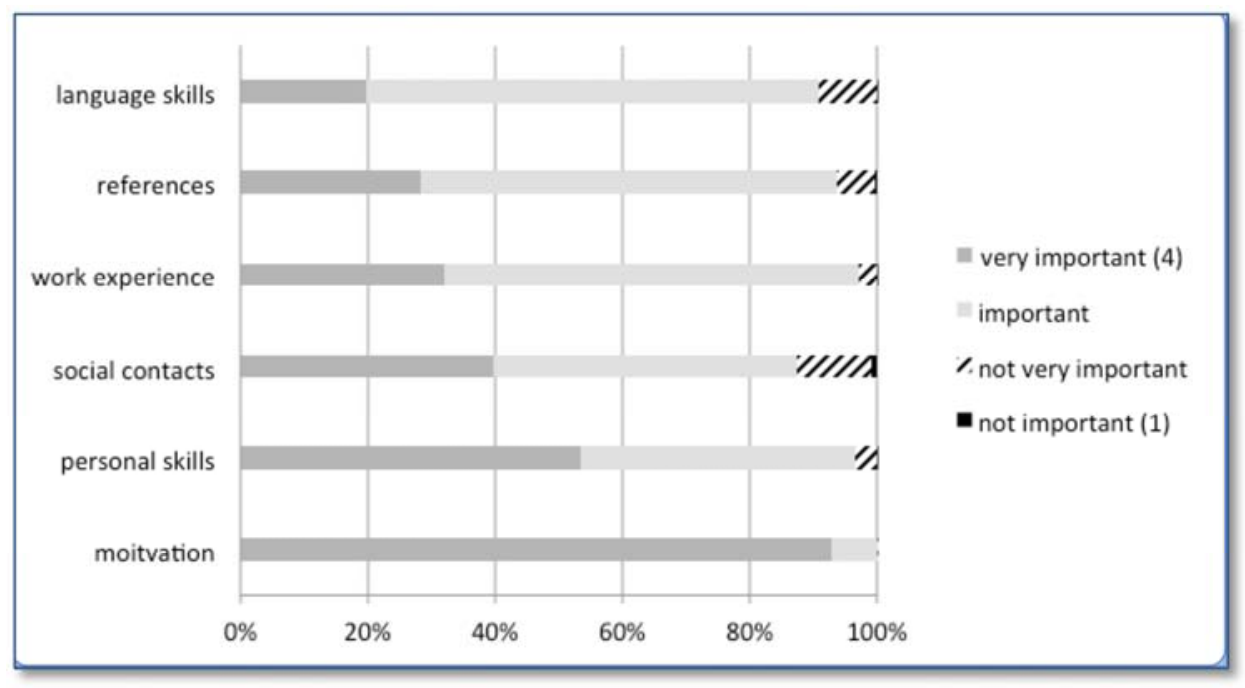

Figure 1. Percentage values of the PA assessing the importance of factors that help the JOS find work $(n=646)$.

Table 3. Mean value and standard deviation of the total sample and in the three linguistic regions, plus univariate anovas.

\begin{tabular}{llllll}
\hline & M, SD Total n=646 & M, SDGermann=279 & M, SDF renchn=299 & M, SD Italiann=68 & $\begin{array}{l}\text { Anova Linguistic region df= 2, } \\
\mathbf{6 4 3}\end{array}$ \\
\hline motivation & $3.9,0.3$ & $3.9,0.2$ & $3.9,0.3$ & $3.9,0.3$ & n.s. \\
personal skills & $3.5,0.6$ & $3.4,0.6$ & $3.6,0.5$ & $3.5,0.6$ & $\mathrm{~F}=18.9^{* * *}$ \\
social contacts & $3.3,0.7$ & $3.1,0.7$ & $3.5,0.6$ & $3.3,0.6$ & $\mathrm{~F}=24.3 * * *$ \\
work experience & $3.3,0.5$ & $3.3,0.5$ & $3.3,0.5$ & $3.3,0.5$ & n.s. \\
references & $3.2,0.6$ & $3.2,0.6$ & $3.3,0.5$ & $3.2,0.5$ & $\mathrm{~F}=4.5 *$ \\
language skills & $3.1,0.5$ & $3.1,0.6$ & $3.1,0.5$ & $3.3,0.5$ & $\mathrm{~F}=3.1^{*}$ \\
\hline
\end{tabular}

Remarks:

- $\mathrm{M}=$ mean value

$-\mathrm{SD}=$ standard deviation

- $\mathrm{n}=$ number of answers per linguistic region

- anovas with significance level of ${ }^{*} \mathrm{p}<.05,{ }^{* *} \mathrm{p}<.01, * * * \mathrm{p}<.001$, n.s. $=$ not significant

$-\mathrm{df}=$ degrees of freedom

Generally speaking, the German-speaking PA consider personal skills, social contacts, job references and language skills less important than those from Romance-language areas. Statistically significant differences however show only small effect sizes [27]. ${ }^{20}$

20 Personal skills: The German-speaking PA judge those skills as significantly less important than the French-speaking $(\mathrm{p}<.001, \mathrm{~d}=0.36)$ and the Italian-speaking PA $(\mathrm{p}<.05, \mathrm{~d}=0.17)$. The latter two do not differ $(\mathrm{p}=.17)$. Social contacts are also judged as less important by the German-speaking PA than by the French-speaking $(\mathrm{p}<.001, \mathrm{~d}=0.62)$ and the Italian-speaking PA $(\mathrm{p}<.05, \mathrm{~d}=0.29)$. The French- speaking PA even judge those as more important than the Italian-speaking ones $(\mathrm{p}<.05, \mathrm{~d}=0.33)$. The German-speaking PA consider references less important than the French-speaking ones $(\mathrm{p}<.01, \mathrm{~d}=0.18)$, but as important as the Italianspeaking ones $(\mathrm{p}=.43)$. The French- and Italian-speaking PA don't differ here $(p=.29)$. The Italian-speaking PA judge the language skills as more important than the German-speaking $(\mathrm{p}<.05, \mathrm{~d}=0.34)$ or the French-speaking PA $(\mathrm{p}<.05, \mathrm{~d}=0.40)$. There is no significant difference between the German- and French-speaking PA $(p=.55)$. The effect size $d$ was calculated using the "soerenwallrodt" calculator. Cohen labels the values of $d=0.2$ as a small, $d=0.5$ as a medium-sized and $d=$ 0.8 as a large effect. 
Among the PA from Romance-language areas the Frenchspeaking and Italian-speaking ones present statistically significant differences only in the evaluation of social contacts and language skills, while the effect size according to Cohen [27] is medium-sized solely regarding the social contacts. The effect regarding language skills on the other hand is rather small. Social contacts in the sense of a social network are clearly considered more important by French-speaking PA and also by PA of other linguistic regions. The Italian-speaking PA on the other hand consider language skills slightly more important than German- and French-speaking PA, though as previously mentioned only with a small effect size.

\subsection{The Benefits of Collective Language Courses}

The most frequent benefit of collective language courses is reaching a minimum level in one of the cantonal languages $(89.5 \%$ completely or mostly agree with this statement, Figure 2). The following question deals with the benefits of integration of the foreign JOS $(81.9 \%)$ and the integration into the labour market (80.5\%). Clearly less PA expect that the courses improve the competences in a second language $(54.3 \%)$ or minimise the return to unemployment $(51.6 \%)$. It is notable that only a little more than one third of the PA (37\%) agree that the linguistic LMM serve to assess the JOS' motivation.

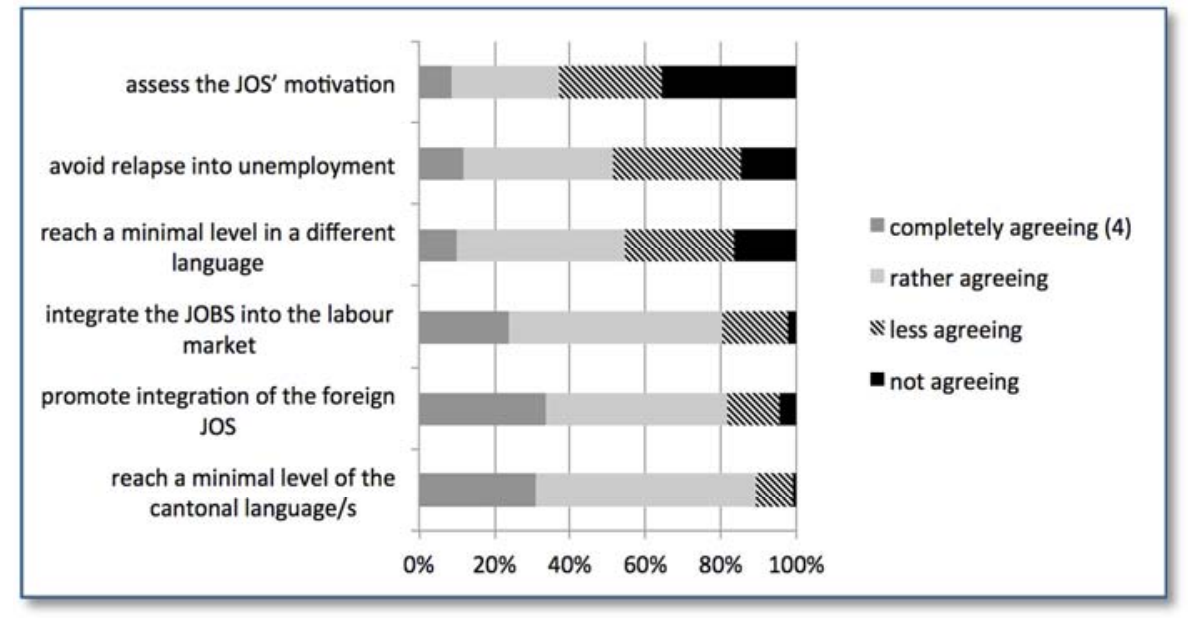

Figure 2. Percentage values of the PA evaluating the benefits of collective language $(n=646)$.

Table 4. Mean value and standard deviation of the total sample and in the three linguistic regions, plus univariate anovas.

\begin{tabular}{|c|c|c|c|c|c|}
\hline & $\begin{array}{l}\text { M, SD Total } \\
n=646\end{array}$ & $\begin{array}{l}\text { M, SD German } \\
n=279\end{array}$ & $\begin{array}{l}\text { M, SD French } \\
\text { n=299 }\end{array}$ & $\begin{array}{l}\text { M, SD Italian } \\
n=68\end{array}$ & $\begin{array}{l}\text { Anova linguistic } \\
\text { region } d f=2,643\end{array}$ \\
\hline Min. level of the cantonal language & $3.2,0.6$ & $3.2,0.7$ & $3.2,0.6$ & $3.4,0.6$ & n.s. \\
\hline Integration of foreign JOS & $3.1,0.8$ & $3.2,0.7$ & $3.0,0.8$ & $3.0,0.9$ & $\mathrm{~F}=6.5 * *$ \\
\hline Integration into the labour market & $3.0,0.7$ & $3.1,0.7$ & $3.0,0.7$ & $2.8,0.9$ & $\mathrm{~F}=3.4 *$ \\
\hline Min. level of other language & $2.5,0.9$ & $2.4,0.9$ & $2.6,0.9$ & $2.6,0.9$ & $\mathrm{~F}=4.4 *$ \\
\hline Decrease of relapse & $2.5,0.9$ & $2.7,0.9$ & $2.3,0.8$ & $2.2,0.9$ & $\mathrm{~F}=21.5 * * *$ \\
\hline Verification of the JOS's motivation & $2.1,1.0$ & $2.3,1.0$ & $1.9,1.0$ & $2.1,0.9$ & $\mathrm{~F}=11.5 * * *$ \\
\hline
\end{tabular}

Remarks:

- $\mathrm{M}=$ mean value

- $\mathrm{SD}=$ standard deviation

- $\mathrm{n}=$ number of answers per linguistic region

- anovas with significance level of $* \mathrm{p}<.05, * * \mathrm{p}<.01, * * * \mathrm{p}<.001$, n.s. $=$ not significant

$-\mathrm{df}=$ degrees of freedom

If you scale these answers again, the order of the mean values becomes apparent, as shown in Figure 2 (mean values and standard deviations see table 4). Here, the consensus also differs among the PA, who don't agree on all aspects according to the standard deviations, in particular concerning the assessment of the motivation $(\mathrm{SD}=1.0)$. These variations can be found statistically through the different evaluations in the three linguistic regions and in all objectives, except when it comes to the acquisition of a minimum level in the cantonal language (see anovas in the last column of table 4).

In a nutshell, the following significant differences show: The German-speaking PA assess the benefits of language courses in general higher than French- and Italian-speaking PA. The only exception is the acquisition of a minimal level in other languages. According to the French-speaking PA, the linguistic LMM are more likely to reach this objective. ${ }^{21}$ In

21 The German-speaking PA evaluate the benefits of linguistic LMM for the integration of foreign JOS significantly higher than the French-speaking $(\mathrm{p}<.01$, $\mathrm{d}=0.27)$ and the Italian-speaking PA $(\mathrm{p}<.05, \mathrm{~d}=0.27)$. The French- and Italianspeaking PA don't differ in their evaluation $(\mathrm{p}=.60)$. The reintegration into the labour market has been judged more important by the German- and Frenchspeaking PA than by the Italian-speaking ones (G-I: p<.05, d=0.4; F-I: $\mathrm{p}<.05$, $\mathrm{d}=0.27$ ), while the German- and French-speaking ones don't differ from each other $(\mathrm{p}=9$ ). The reaching of a minimal level in a different language is more important to the German-speaking PA than to the French-speaking ones (G-F: 
accordance with effect sizes, the differences regarding a decrease in return to unemployment are medium-sized, otherwise rather small.

\section{Discussion}

Language skills undisputedly represent an additional benefit for labour market integration according to the PA. A first indication of the importance of this subject for the REC advisers is the very high response rate of this questionnaire with $54 \%{ }^{22}$ The overrepresentation of French-speaking advisers in this survey should not be considered as a bigger interest for this subject matter in this linguistic region but as a consequence of the participating cantons: Geneva, Vaud and Valais cover a big part of French-speaking Switzerland, while Zurich, the most populated German-speaking canton, didn't participate in the survey. It's striking that roughly more than three quarters of the respondents are multilingual and thus able to advise the JOS in two or more languages. This means that the representations of the PA regarding language skills are certainly also strongly characterised by their individual experiences and by their own competences. But does "the" PA with standardised representations exist? In certain areas they do, in others they do not. The following chapters describe these differences more in detail.

\subsection{The Additional Benefit of Languages in Different Professions}

In line with the experience of most of the REC advisers, the mastery of one of the national languages is an additional benefit to find work in that linguistic region. It is not surprising that the local language is the most important language for (almost) any profession in each linguistic region. Exceptions are professions in the tertiary sector. According to most of the PA, Swiss German plays an important role in all linguistic regions, especially in Germanspeaking Switzerland which is obvious but also in Frenchand even more so in Italian-speaking Switzerland. The presence of German, or rather Swiss German in the tertiary sector of Italian-speaking Switzerland, as perceived by the PA, can be explained with the many Swiss German tourists and "emigrated" Swiss Germans in Ticino.

Along with the national languages and the Swiss German dialect, English also represents one of the many additional benefits mentioned by the PA. Bank employees in Germanspeaking Switzerland as well as French-speaking Switzerland even consider English more useful than German or French. Other non-national languages such as the rather "older"

$\mathrm{p}<.01 ; \mathrm{d}=0.22)$. No significant differences are evident between the other groups (G-I: $\mathrm{p}=.09$; F-I: $\mathrm{p}=.9$ ). The reduction of a relapse into unemployment significantly differs between the German- and French/Italian-speaking PA (G-F : $\mathrm{p}<.001, \mathrm{~d}=0.47$; G-I: $\mathrm{p}<.001, \mathrm{~d}=0.56$ ), while the French- and Italian-speaking PA agree with each other (F-I: $p=.2$ ). In the examination of motivation the Germanspeaking PA differ from the French-speaking ones $(\mathrm{p}<.001, \mathrm{~d}=0.4)$, the other groups, however, don't (G-I: $\mathrm{p}=.2, \mathrm{~F}-\mathrm{I}: \mathrm{p}=.09$ ).

22 Schonlau et al. [28] write that response rates for online or mail surveys usually range from 7 to $44 \%$ languages spoken by migrants Portuguese and Spanish are only considered a minimal additional benefit in specific sectors (such as in agriculture and the construction sector) while Spanish also seems to have a special value in the hotel industry. For many PA, the "newer" languages spoken by migrants Albanian and Serbo-Croatian are practically of no additional benefit. At the same time, the French-speaking PA attribute more additional benefit to those non-national languages as the German- and Italian-speaking PA.

Generally, it is safe to assume that most of the PA confirm the economical hierarchisation of the national languages German and French and consider the international language English a key linguistic capital. However, there are differences in Switzerland depending on the linguistic region: as expected, in Italian-speaking Switzerland Italian occupies the most important position, followed by German/Swiss German.

\subsection{The Importance of Language Skills}

Most REC advisers see language competence as one of various important elements in the process of labour market integration, though not the most important one. For all PA, the most important element is the motivation of the JOS, without differences between the PAs' linguistic regions. Regarding all other factors, except work experience, there are statistical differences depending on the language region. When it comes to the evaluation of language skills, their importance for the Italian-speaking advisers stands out. What is more, the evaluations regarding the additional benefit of language skills (see first question) show that PA in Italianspeaking Switzerland consider the national language of German as well as Swiss German varieties very popular in the service sector in particular (bank, reception, service). This leads to the conclusion that multilingual competences have a stronger impact on labour market integration in Ticino than in other linguistic regions of Switzerland.

It's interesting that German-speaking PA deem social contacts less crucial for a successful job search as the Frenchspeaking PA. A study in the canton of Vaud found that social contacts are paramount for labour market integration even if its impact varies depending on the group of persons and the industry sector [22]. The question which arises is whether the JOS' social network in German-speaking Switzerland has a less important role when it comes to offering jobs or whether its benefits are rather underestimated by the Germanspeaking REC advisers.

Collective language courses serve the purpose of learning a cantonal language. There is a strong consensus on that among the PA. Apart from this, two main objectives of the language courses are the integration of foreign jobseekers and the integration into the labour market. The last point is not particularly surprising since the main purpose of LMM for the unemployment insurance is the increase in the JOS' employability. In purely numerical terms, there is a disproportionate number of unqualified or rather low-skilled workers among the jobseekers that don't necessarily master the local language very well [29]. To what extent it is, 
however, the function of the unemployment insurance to help with social integration of foreign jobseekers by means of linguistic LMM, remains a question of the REC employees' attitude and could be subject of a political discussion to create more clarity for the REC advisers. In this respect, it is noticeable that, generally speaking, the German-speaking advisers see a larger benefit in linguistic LMM than the advisers from the French- and Italien-speaking areas.

The participation in language courses is however considered less effective for a permanent integration into the labour market than expected, since the objective of the LMM is not only a quick but also a durable integration into the labour market. It is possible that there are factors other than language skills that increase the risk of relapsing into unemployment. As mentioned in the beginning, the study by Ecoplan [14] on repeated unemployment shows that unemployed persons of foreign origin are more often affected by repeated unemployment than unemployed persons with a Swiss citizenship. The simultaneously conducted qualitative ethnographic study carried out by the colleagues from the Research Centre on Multilingualism [30] shows that foreign JOS, who are frequently less educated, are assigned less advanced LMM. Most of the PA surveyed in the canton of Fribourg assume that less well-educated JOS quickly find employment again in the auxiliary work sector and this also without a good knowledge of the local language. Therefore for these PA a relapse into unemployment is not primarily depending on language skills. Other PA, mainly Germanspeaking ones, disagree on this according to the online survey: according to them, linguistic LMM can help avoid a relapse into unemployment. In summary, a clarification could help the PA to know how they can support interested JOS with lower qualifications and little knowledge of the national languages in language acquisition.

Even though the aspect concerning motivation is seen as the main factor for a successful integration into the labour market in all linguistic regions, the PA agree less on the question to what extent it is their role to verify this motivation by means of LMM. The PA presumably more or less take on the "authoritarian" role of the state as Magnin calls it [2: 359]. The results of the current study show that the PA in the different linguistic regions see their role differently when it comes to the examination of the motivation: the German-speaking PA make use of the supervisory function of linguistic LMM more frequently than the PA of the other two linguistic regions. Although linguistic LMM are used by all PA for the learning of an official local language, the improvement of linguistic skills in other foreign languages seems to be more important to the PA from Romancelanguage areas than to those from German-speaking areas. When looking at the language distribution in Switzerland, this difference is entirely explainable. In 2012 the structural survey of the national census showed that $64.9 \%$ of the Swiss population indicated German, 22.6\% French, 8.3\% Italian, $0.5 \%$ Rhaeto-Romanic and $21 \%$ a non-national language as one of their main languages. Purely proportionally speaking, it thus makes sense that the speakers of a Latin language learn the majority language, that is, German, since it is more useful for them than it is for the German-speaking persons to communicate in the language of a Swiss minority. This interpretation is especially confirmed by the Italian-speaking PAs' high estimation of the additional benefit of German.

\section{Conclusion}

Set against this presented background, one might say that a PA symbolically represents the two-faced Janus, the mythical figure of beginning and transition. One can imagine this Janus looking into the future of possible labour market integration with one face and evaluating the JOS' displayed motivation in the past and the present with the other face. Thus, the PA are in fact at the gateway to government services and decide about the additional benefit and the promotion of certain language skills. For this double role of the PA a clarification would certainly be helpful, first regarding their role as promoters of foreign JOS' social integration; and secondly to define to what extent they could or should support interested and low-skilled JOS with little knowledge of the national languages at language acquisition.

Almost twenty years have passed since the professionalization of the REC and the expansion of the LMM and different revisions of the law on unemployment have been carried out. According to today's point of view of all the REC advisers, it has however remained the same; that the JOS' proactivity, i.e. their own motivation, appears to be one of the most important factors when it comes to a successful job placement. This is an indication that the policy of activation has established itself in practice during these years. What is more, the study carried out by Morlok et al. [31], which, by means of the number of submitted applications, researches successful labour market integration, makes this policy and practice visible. For the PA on the one hand, this means that their daily work is characterised by the evaluation and promotion of the JOS' motivation. For the JOS on the other hand, it means that they can expect different government services depending on the degree of actual or rather displayed motivation. There presumably is great potential for conflict, which is only intensified by the PAs' and JOS' different moral concepts. Thus, the employment placement project is shaped by individual negotiations between the PA and the JOS, which could also affect the promotion of language skills. Here again the previously mentioned clarifications could be beneficial for the PA.

But there are also different moral concepts to be found among the PA working in Switzerland's different linguistic regions. On the one hand, these are certainly explicable with the different cantonal guidelines and should be examined more closely by means of an analysis of the internal documents as well as the institutional discourses. Furthermore, a structural factor, namely that of the unemployment rate in the region of the REC, undoubtedly plays a representation-forming role. On the other hand, the differences by linguistic region level can be interpreted as a different cultural set of values, for instance when it comes to 
the welfare state [16]. For this purpose a further study on the correlation of unemployment rate (over a certain period of time) and the representations of cause and effect of unemployment in Switzerland's different linguistic regions would certainly be insightful.

\section{Limitations of This Study}

Three major limitations can be mentioned. First, the analysed data show the representations of the PA and their declared practice on assessing and valuating language skills, but they do not show what the PA actually do in reality on that matter. Secondly, the data represent only PAs' representations of some Swiss cantons but not of all of them. The French-speaking population is slightly over represented in this sample. And at last, the data is of a quantitative nature and therefore does not allow for any qualitative interpretations. There was however the above-mentionedconnected study, which followed a qualitative approach of the current issue [30].

\section{Outlook}

Against this backdrop, the PA have a crucial but difficult role when it comes to the evaluation of the jobseekers' language skills. Their representations of the measures which should be prescribed to unemployed and jobseekers indicate both similarities and differences. The question therefore arises of the extent to which the PAs' representations align with those of the other actors in this area, for instance the JOS' or the employers'. In addition to this, it would be interesting to research if or to what extent language skills in non-national languages like Spanish or Portuguese have an influence on remuneration in Switzerland. It so happens that in Western European countries that, like Switzerland, live from tourism to a considerable extent, second language skills increase the salary by 3 to 5 percent [32]. Studies from Switzerland seem however to rather imply that the language resources of employees with a migration background are mostly seldom rewarded by employers [33, 34, 35]. The observations about the PA regarding the additional benefit of the different languages also indicate a de-valuing of the languages spoken by migrants. The question arises if thorough evaluations of salaries in the banking sector, in tourism regions or even of REC employees would confirm this.

\section{Acknowledgements}

The project has been financed by the funds of the Research Centre on Multilingualism in Fribourg, Switzerland. Special thanks go to our colleagues for their valuable cooperation: Renata Coray, Mi-Cha Flubacher and Alexandre Duchêne as well as Ana Terrier, Sabine Christopher Guerra and Orest Weber. For the translation, our thanks got to Katrin Meyfarth and Suzanne Balharry. We would also like to thank all the employees from the REC whose active participation has contributed to this research paper.

\section{Declaration}

"We hereby declare that this original contribution has not been published yet and will not be submitted for publication elsewhere without the approval of the editorial board of the International Journal of Language and Linguistics."

"The authors declare that they have no competing interests."

\section{References}

[1] Magnin, C.: Chance oder Zumutung? Eine soziologische Studie zur Beratungspraxis von regionalen

Arbeitsvermittlungszentren in der Schweiz. Kurzfassung, NFP Projekt Nr. 4045-59631.

http://www.snf.ch/SiteCollectionDocuments/nfp/nfp45/NFP45 _Magnin_SB.pdf. (2003). Accessed 19 February 2015

[2] Magnin, C.: Beratung und Kontrolle. Ein für den aktivierenden Staat typisches Handlungsdilemma. Swiss Journal of Sociology 30(3), 339-361 (2004)

[3] Erickson, F., Schultz, J.: The Counselor as Gatekeeper: Social Interaction in Interviews. Academic Press, New York (1982)

[4] Semadeni, F.: Chancen und Grenzen im System. Die Anerkennung von Kompetenzen im Rahmen von arbeitsmarktlichen Massnahmen. PowerPoint presentation at the panel "Kompetenzen aber kein Diplom" on the 29 March 2012 in Bern. http://www.arbeitsintegration.ch/media/files/Referat-Semadeni.pptx (2012). Accessed 18 February 2015

[5] Grin, F., Sfreddo, C., Vaillancourt, F.: The Economics of the Multilingual Workplace. Routledge, New York/London (2010)

[6] Lüdi, G., Höchle, K., Yanaprasart, P.: Plurilingual practices at multilingual workplaces. In: Apfelbaum, B., Meyer, B. (eds.) Multilingualism at Work, pp. 211-234. John Benjamins, Amsterdam (2010)

[7] Coray, R., Kobelt, E., Zwicky, R., Kübler, D., Duchêne, A.: Mehrsprachigkeit verwalten? Spannungsfeld Personalrekrutierung beim Bund. Seismo, Zürich (2015)

[8] Christopher, S., Zurbriggen, S.: Implementation of multilingual status and acquisition planning in the Swiss Federal Administration. In: Pandolfi, E., Miecznikowski, J., Christopher, S. and A. Kamber (eds.) Duisburger Arbeiten zur Sprach- und Kulturwissenschaft. Studies on Language Norms in Context, pp. 73-102. (2017)

[9] Bundesamt für Statistik. Statistik Schweiz. Migration und Integration - Indikatoren, Bevölkerung mit Migrationshintergrund.

http://www.bfs.admin.ch/bfs/portal/de/index/themen/01/07/bla nk/key/04.html (2015). Accessed 27 March 2015

[10] Bourdieu, P.: Ce que parler veut dire. L'économie des échanges linguistiques. Fayard, Paris (1982)

[11] Grin, F.: Langue et differentials de statut socio-économique en Suisse. Bundesamt für Statistik, Bern (1997)

[12] Grin, F., Sfreddo, C: Language-Based Earnings Differentials on the Swiss labor Market: Is Italian a Liability? International Journal of Manpower 19, 520-532 (1998) 
[13] Christopher, S., Zurbriggen, S.: Mehrsprachigkeit in der Bundesverwaltung: Analyse der Umsetzung des gesetzlichen Auftrags. Bulletin VALS-ASLA T3, 81-97 (2015)

[14] Ecoplan: Auswirkungen der Arbeitslosigkeit auf Einkommen und Erwerbsbiografien. Eine quantitative Analyse für die Schweiz im Zeitraum 1993 bis 2010. SECO publikation 34. http://www.seco.admin.ch/dokumentation/publikation/00004/0 0005/05222/index.html (2013). Accessed 19 February 2015

[15] Brügger, B., Lalive d'Epinay, R., Zweimüller, J.: Regionale Disparitäten in der Arbeitslosigkeit: Kulturelle Grenzen und Landesgrenzen. SECO publication 23. http://www.seco.admin.ch/dokumentation/publikation/00004/0 2085/index.html?lang=de (2007). Accessed 19 February 2015

[16] Flückiger, Y., Kempeneers, P., Deutsch, J., Silber, J., Bazen, S.: Analyse des différences régionales de chômage/ Analyse der regionalen Unterschiede in der Arbeitslosigkeit. SECO publication 22 .

http://www.seco.admin.ch/dokumentation/publikation/00004/0 2093 (2007). Accessed 19 February 2015

[17] Staatssekretariat für Wirtschaft SECO. Arbeitslosenquote nach Kantonen. https://www.amstat.ch/v2/index.jsp (2015). Accessed 15 June 2016

[18] Laplantine, F.: Anthropologie des systèmes de représentations de la maladie: de quelques recherches menées dans la France contemporaine réexaminées à la lumière d'une expérience brésilienne. In: Jodelet, D. (ed.) Les représentations sociales, pp. 277-298. Presses Universitaires de France, Paris (1989)

[19] Staatssekretariat für Wirtschaft SECO. AVIG-Praxis AMM http://www.treffpunkt-arbeit.ch/dateien/Kreisschreiben/D-

Kreischreiben_AMM_2014.pdf(2014). Accessed 15 June 2016

[20] Kaltenborn, B., Kaps, P.: Steuerung der öffentlichen Arbeitsvermittlung in der Schweiz. SECO-Publikation 35. www.seco.admin.ch/dokumentation/publikation/00004/00005/ 05228/ index.html (2013). Accessed 27 March 2007

[21] Häubi, R., Fontaine, P., Gast, J., Benelli, E.: Arbeitslosigkeit in der Schweiz 2012. SECO/ BFS, Neuchâtel (2013)

[22] Bonoli, G., Lalive d'Epiney, R., Oesch, D., Turtschi, N., von Ow, A., Arni, P., Parrotta, P.: L'impact des réseaux sociaux sur le retour à l'emploi des chômeurs. SECO publication 37. http://www.seco.admin.ch/dokumentation/publikation/00004/i ndex.html?lang=en (2013). Accessed 28 January 2014

[23] Maurer, E.: Deutsch für den Arbeitsmarkt. Rahmenkonzept für Projektverantwortliche und Lehrpersonen. Klett und Balmer Verlag, Zug (2010)

[24] Maurer, E., Ecoeur, Y.: Du français pour travailler. Un concept cadre pour responsables de projets et de cours. Klett und Balmer Verlag, Zug (2010)
[25] Bundesamt für Statistik. Statistik Schweiz. Sprachen, Religionen-Daten, Indikatoren. http://www.bfs.admin.chbfs/portal/de/index/themen/01/05/bla nk/key/sprachen.html (2015). Accessed 24 February 2015

[26] Staatssekretariat für Wirtschaft SECO. Die Lage auf dem Arbeitsmarkt.

https://www.amstat.ch/seco/pressedoku/201502_Pressedoku_d e.pdf (2015). Accessed 15 June 2016

[27] Cohen, J.; Statistical Power Analysis for the Behavioral Sciences. Lawrence Erlbaum Associates, Hillsdale (1988)

[28] Schonlau, M., Fricker, R., Elliott, M.: Conducting Research Surveys via E-mail and the Web. RAND, Santa Monica (2002)

[29] Spycher, S., Detzel, P., Guggisberg, J., Weber, M., Schär Moser, M., Baillod, J.: Etrangers, étrangères, chômage et assurance-chômage. Synthèse d'un projet de recherche mené dans le cadre de l'évaluation de l'impact des mesures de marché du travail de l'assurance-chômage/ Ausländer/innen, Erwerbslosigkeit und Arbeitslosenversicherung. Synthese eines Forschungsprojektes im Rahmen der Wirkungsevaluation der aktiven Arbeitsmarktmassnahmen der Arbeitslosenversicherung. SECO publication 16. http://www.seco.admin.ch/dokumentation/publikation/00004/0 0005/01793/index.html (2006). Accessed 27 March 2015

[30] Duchêne, A., Singy, P., Coray, R., Flubacher, M., Zurbriggen, S., Pante, I.: Öffentliche Arbeitsvermittlung und Sprachkompetenzen / Placement public et compétences linguistiques. Interner Schlussbericht KFM, Fribourg (2015)

[31] Morlok, M., Liechti, D., Lalive d'Epinay, R., Osikominu, A., Zweimüller, J.: Evaluation der arbeitsmarktlichen Massnahmen Wirkung auf Bewerbungsverhalten und chancen. SECO publication 41 . http://www.seco.admin.ch/dokumentation/publikation/00004/0 5435/index.html (2014). Accessed 18 February 2015

[32] Williams, D.: Multiple language usage and earnings in Western Europe. International Journal of Manpower 32 (4), 372-393 (2011)

[33] Grin, F: Compétences et récompenses: la valeur des langues en Suisse. Editions Universitaires Fribourg, Fribourg (1999)

[34] Heller, M.: Language as resource in the globalized New Economy. In: Coupland, N. (ed.) The Handbook of Language and Globalization, pp. 349-365. Blackwell, Oxford (2010)

[35] Flubacher, M., Duchêne, A.: Eine Stadt der Kommunikation: urbane Mehrsprachigkeit als Wirtschaftsstrategie? Bulletin VALS/ASLA 95, 123-142 (2012) 